\title{
Biodiversity of Symbiotic Microorganisms of Caulerpa racemosa from Lemukutan Island, Indonesia and Its Antibacterial Activity
}

\author{
Warsidah ${ }^{1, *}$ Rizky ${ }^{1}$, Mega Sari Juane Sofiana ${ }^{1}$, Ikha Safitri ${ }^{1}$, Sukal Minsas ${ }^{1}$, Melia \\ Trianasta $^{1}$, Susi Sumanti ${ }^{1}$
}

${ }^{1}$ Department of Marine Science Universitas Tanjungpura, Pontianak, Indonesia

*Corresponding author. Email: warsidah@fmipa.untan.ac.id

\begin{abstract}
Symbiotic microorganisms usually have the same secondary metabolite activity as their host. The aims of this study were determine the biodiversity of symbiotic microorganisms from Caulerpa racemosa grown in Lemukutan Island, Indonesia and evaluate their antibacterial activity. Thirty eight bacterial and eighteen fungal were isolated. All isolates showed antibacterial activity against Escherichia coli and Staphylococcus aureus. All fungal isolates were identified from spore morphology using a microscope and, the best bacterial isolates with highest antibacterial activity (IB21 and IB47) were identified using biochemical tests, such as gram staining, citrate test, MR-VP test, carbohydrate fermentation test, fermentative oxidation test, oxidation test, catalase test, indole test, motility test, urease test and hydrogen production test (H2S). The genera of isolated fungi were identified as genus Trichocladium, Aspergillus, Chaetomium, Coprinus, Cladorrhinum, Hymeochaete, Rhizopus, Tremella, Zygorhynchus, Mucor, and Bjerkandera. Meanwhile the best bacteria IB21 and IB47 were putatively identified as member of genus Corynebacterium and Neissiria, respectively.
\end{abstract}

Keywords: Antibacterial Activity, Biodiversity, Caulerpa racemosa, Microorganism.

\section{INTRODUCTION}

Indonesian marine waters have a high biodiversity of marine organisms, such as macroalgae. It was found 555 species out of 8,000 species of total world macroalgae biodiversity [1]. The diversity and community of macroalgae influenced by oceanographic, topographic, and biological factors [2]. Macroalgae are classified into three groups, namely brown (Phaeophyta), red (Rhodophyta) and green macroalgae (Chlorophyta). Macroalgae have a crucial role in primary productivity, absorbing pollutants, producing organic matter and oxygen for another aquatic biota. In addition, the ecological role of macroalgae is habitat for feeding, spawning, and nursery grounds [3] for other organisms.

Macroalgae is one of the marine resources in bioactive compounds. Macroalgae from the waters of West Kalimantan, namely Eucheuma spinosum from Lemukutan Island and Padina pavonica Hauck from Kabung Island have antioxidant activity [4],[5]. Antibacterial and antioxidant properties of Caulerpa racemosa and $C$. lentillifera have also been reported [6].
These bioactive compounds are secondary metabolites produced by macroalgae as a form of self-defense from unfavorable environmental conditions and pathogenic microbes. Bioactive compounds can also obtained from symbiotic microorganisms. Proksch [7] have reported that the bioactive compounds of symbiotic microorganisms are identical to those of the host. Therefore, symbiotic microorganisms have the potential as a source of bioactive compounds. Symbiont bacteria are more effective to use than crude extract of macroalgae because they are easy to culture in the laboratory, thus they can avoid excessive use of natural materials [8].

The bioactivity of bacterial and fungal symbionts has been widely reported. Antibacterial of CR2 bacterial isolates associated with $\mathrm{C}$. racemosa was active against Pseudomonas aeruginosa and HM isolates associated with Halimeda macroloba were active against Escherichia coli and P. aeruginosa [9]. Bacteria associated with green macroalgae from Singkawang waters obtained 3 isolates of bacteria associated with $C$. racemosa and 4 isolates of bacteria from Caulerpa taxifolia had antibacterial activity [10]. Fungi symbionts 
(FSUr-1, FSUr-2, FSUr-3) from Ulva reticulata from Takalar, South Sulawesi also showed antibacterial and antifungal activity [11] Aspergillus nomius associated with Bornetella sp. showed antibacterial against $E$. coli and Staphylococcus aureus [12]. The bioactivity of this symbiotic microorganisms indicates that the microorganism has great potential as an antibacterial. Therefore, the aimed of this research are determine the biodiversity of the symbiotic microorganisms of $C$. racemosa and its antibacterial activity.

\section{MATERIALS}

Materials used in this research were NB (Nutrient Broth), NA (nutrient agar), seawater, PDA (Potato Dextrose Agar), and Zobell 2216E, C. racemosa, bacteria test ( $S$. aureus and E. coli), alcohol, aquades, set of biochemical test materials and phytochemical reagent kits, chloramphenicol (50 mg/L), and $1 \%$ sodium hypochlorite.

\section{METHODS}

\subsection{Sampling}

Samples of macroalgae C. racemosa was collected from Lemukutan Island, Indonesia, in 6 and 7 December 2020. The sample was taken at a depth of $0,9-1,3$ meters with coordinate N $00^{\circ} 46^{\prime} 48.46^{\prime \prime}$ E $108^{\circ} 42^{\prime} 23.91$ " (Figure 1). The sample was put into a sterile plastic bag containing seawater and then stored in a cool box containing ice cubes for further analysis in the laboratory.

\subsection{Isolation of Microorganisms}

Isolation of fungi and bacteria was conducted using two methods, namely serial dilution, and direct method. The sample washed with flowing water and then the surface was sterilized by immersing the sample in $1 \%$ sodium hypochlorite solution for 5 minutes, $70 \%$ ethanol for 1 minute and in the end washed with sterile distilled water [20]. Sample crushed using a mortar and put into an erlenmeyer and added $100 \mathrm{~mL}$ sterile seawater (stock solution). The sample suspension from the stock solution was taken $1 \mathrm{~mL}$ and then put into $9 \mathrm{~mL}$ of sterile seawater to produce a $10^{-1}$ dilution, the same way was done to produce a $10^{-2}$ to $10^{-5}$ dilution [16]. The isolate with a dilution of $10^{-3}$ to $10^{-5}$ were inoculated with $1 \mathrm{~mL}$ in PDA (Potato Dextrose Agar) dissolved in distilled water and PDA dissolved in seawater, using pour plate methods [14], [18]. Chloramphenicol was added for inhibiting bacterial growth. Then, sample were incubated for 5-7 days at room temperature. For bacterial isolation, the isolate with the same dilution of $10^{-3}$ to $10^{-5}$ were inoculated with $1 \mathrm{~mL}$ in NA and Zobell $2116 \mathrm{E}$ by pour plate methods. After that, sample were incubated for 5-7 days at room temperature.

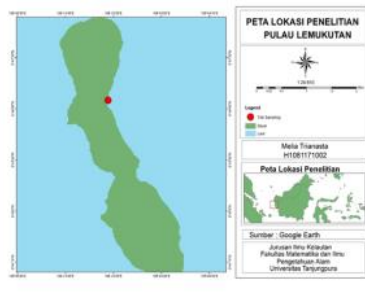

A

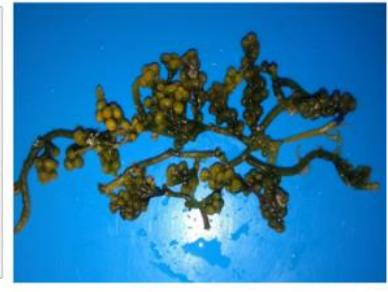

B
Figure 1 Sampling location (A), and C. racemosa (B).

Fungi isolation using direct method. The sample washed with flowing water and then the surface was sterilized by immersing the sample in a $1 \%$ sodium hypochlorite solution for 5 minutes, $70 \%$ ethanol for 1 minute and in the end washed with sterile distilled water [20]. Samples were inoculated directly on PDA surface agar. Samples were incubated for 5-7 days at room temperature. For bacterial isolation, samples inoculated on the NA and Zobell 2216E. Samples were incubated for 24 hours at room temperature.

\subsection{Screening Antibacterial Activity Test}

Antibacterial activity test of fungal isolates was carried out using the agar diffusion methods. Colonies of endophytic fungal isolates of green macroalgae $\mathrm{C}$. racemosa were grown for 7 days then cut $(6 \mathrm{~mm}$ in diameter) and placed on NA which had been spreading with bacterial test and incubated at $37^{\circ} \mathrm{C}$ for 2 days. Antibacterial activity showed by formation of inhibition zone [19].

Antibacterial activity test of bacterial isolates was carried out by cross streak method. Colonies of bacteria were grown perpendicular to bacteria test and incubated at $37^{\circ} \mathrm{C}$ for $1 \times 24$ hours. Antibacterial activity indicated by the formation of a clear zone [25].

\subsection{Characterization of the Isolate Microorganism}

Identification of endophytic fungal isolates were carried out based on identification book Pictorial Atlas of Soil and Seed Fungi Morphologies of Cultured Fungi and Key to Species, [22] and referring to the journal [21], [23], and [24]. Thus, macroscopic (colony color, and colony shape) and microscopic observations were conducted under a light microscope with a magnification of 100x [20].

Identification of bacterial isolates were using biochemical tests, namely gram staining, citrate test, MRVP test, carbohydrate fermentation test $(\mathrm{D}(+)$-glucose, sucrose, lactose, maltose, and $\mathrm{D}(+)$-mannitol), fermentative oxidation test, oxidase test, catalase test, indole test, motility test, urease test and hydrogen sulphide test $\left(\mathrm{H}_{2} \mathrm{~S}\right)$. 


\subsection{Fermentation of Bacterial Suspension}

Fermentation test used isolates using two bacteria with the highest antibacterial activity such as IB21 and IB47. The suspension of bacteria was grown in NB media, then agitated at $170 \mathrm{rpm}$ for 24 hours. The suspension was centrifuged at 3,000 rpm for 30 minutes to separate the supernatant. The supernatant was used for phytochemical tests [35]

\subsection{Phytochemical Activity Test of Bacterial Suspension}

Phytochemical tests were conducted following to method by Masriani [37] to identify flavonoids, alkaloids, steroid/sterpenoids, sapponins, and phenolics compounds.

\section{RESULT AND DISCCUSSION}

\subsection{Sampling and Isolation of Microorganisms}

Samples of $C$. racemosa were taken under temperature of $29.53^{\circ} \mathrm{C}$, salinity of $32.37 \mathrm{ppt}$, $\mathrm{pH}$ of 8.046 and DO of $4.63 \mathrm{mg} / \mathrm{L}$. A total of 38 of bacteria and 18 of fungi were isolated (Figure 2). Furthermore, the isolates were tested for antibacterial activity.

\subsection{Screening of Antibacterial Activity}

Screening of antibacterial activity of symbiotic microorganisms were conducted (Table 1). Two bacterial isolates (IB21 and IB47) showed highest antibacterial activity based on the formation of highest clear zone diameter. This is accordance with the research of Yap et al [6] C. racemosa had antibacterial activity against pathogenic bacteria (E.coli and S.aureus). Similar research carried out by Rahaweman et al. [14] 13 fungal isolates from macroalgae Caulerpa spp., Halimeda spp., and Sargassum spp. Kepulauan Seribu, Indonesia has antibacterial activity against pathogenic bacteria $S$. aureus and E. coli. Similar research was also conducted too by Ismail et al. [13]. A total of 26 bacterial isolates from the macroalga Padina pavonica had antibacterial activity against 12 pathogenic bacteria such as $S$. aureus, E. coli, A. salmonicida, A. hydrophila, E. xiangfangensis, E. faecium, Micrococcus sp., S. typhimurium, Streptococcus sp., V. alginoliticus, V. proteolyticus, and V. vulnificus. Another 19 isolates bacterial and fungi can inhibit only one of gram positive or negative pathogenic bacterial (Table 1). This could be due to differences in composition and structure of peptidoglycan in pathogen bacterial cell wall (E. coli and S. aureus) which can affect antibacterial activity [15].

\subsection{Characterization of Microorganism}

The biochemical test of IB21 (Table 2) showed positive result in metabolite products, namely: methyl red, O/F and simon citrate. IB21 was motile and grampositive. Positive result in enzyme characteristic test, namely: oxidase and catalase, and negative of lactose test in carbohydrate fermentation. IB21 was bacilli. The results of the identification of bacteria based on Bergey's Manual of Determinative Bacteriology (1994) isolates IB21 suspected of the genera Corynebacterium. The biochemical test of IB47 (Table 2) show positive result in metabolite products, namely: indole, methyl red and O/F. IB47 had positive result in enzyme characteristic test, namely: oxidase and catalase, and positive result on sucrose and D(+)-glucose. IB47 was coccus, motile and gram-negative. The results of the identification, IB47 suspected of the genera Neissiria. Corynebacterium and Neissiria were obtained from marine environments such as algae [33], [38].

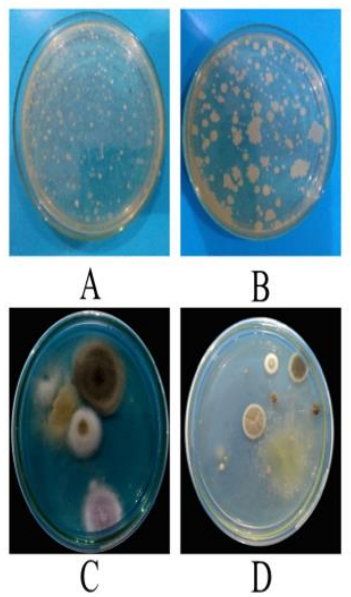

Figure 2. Symbiotic microorganisms $(A, B)$ bacteria (C,D) fungi.

Endophytic fungal of $C$. racemosa from Lemukutan Island waters were identified macroscopically and microscopically. Macroscopic identification was carried out by looking at the color differences of fungi isolated colonies and light microscope with magnification of 100X (Table 3). The hyphae characteristics obtained from microscopic observations were matched with standard micrographs from identification books to determine the genus [22]. Based on the identification results, the genera of fungal isolates are Trichocladium, Aspergillus, Chaetomium, Coprinus, Cladorrhinum, Hymeochaete, Rhizopus, Tremella, Zygorhynchus, Mucor, and Bjerkandera. The most dominant genus of endophytic fungal isolates obtained was the genera Aspergillus. (Table 3).

Aspergillus commonly found in marine, such as macroalgae from different aquatic origins [26], [27], [28]. It was strengthened by the research of [29], [30], [31], that endophytic fungal of $C$. racemosa and sponges from India identified as the genera Aspergillus, Penicillium, Cladosporium, Monascus, and Schizophyllum. Other endophytic fungal genera and species were also identified by Ahamed and Murugan [28]; Handayani et al [32] from macroalgae namely Chaetomium and Trichoderma harzianum 
Table 1. Screening of Antibacterial Activity

\begin{tabular}{|c|c|c|c|c|}
\hline \multirow{2}{*}{ No. } & \multirow{2}{*}{ Isolates } & \multirow{2}{*}{ Medium } & \multicolumn{2}{|c|}{ Antibacterial Activity } \\
\hline & & & E. coli & S. aureus \\
\hline 1 & IB02 & NA & + & \pm \\
\hline 2 & IB04 & NA & + & \pm \\
\hline 3 & IB06 & NA & + & - \\
\hline 4 & IB08 & NA & \pm & - \\
\hline 5 & IB09 & NA & + & - \\
\hline 6 & IB 10 & NA & \pm & \pm \\
\hline 7 & IB13 & NA & + & - \\
\hline 8 & IB17 & NA & - & \pm \\
\hline 9 & IB 18 & NA & - & - \\
\hline 10 & IB21 & NA & + & + \\
\hline 11 & IB24 & NA & \pm & \pm \\
\hline 12 & IB25 & NA & + & - \\
\hline 13 & IB29 & NA & \pm & + \\
\hline 14 & IB32 & NA & \pm & \pm \\
\hline 15 & IB38 & Zobell 2216E & + & - \\
\hline 16 & IB39 & Zobell 2216E & - & + \\
\hline 17 & IB45 & Zobell 2216E & \pm & - \\
\hline 18 & IB46 & Zobell 2216E & - & - \\
\hline 19 & IB47 & Zobell 2216E & + & + \\
\hline 20 & IB48 & Zobell 2216E & + & - \\
\hline 21 & IF01 & NA & \pm & \pm \\
\hline 22 & IF02 & NA & - & \pm \\
\hline 23 & IF03 & NA & + & \pm \\
\hline 24 & IF04 & NA & - & \pm \\
\hline 25 & IF05 & NA & - & \pm \\
\hline 26 & IF06 & NA & - & \pm \\
\hline 27 & IF07 & NA & + & \pm \\
\hline 28 & IF08 & NA & - & \pm \\
\hline 29 & IF09 & NA & - & \pm \\
\hline 30 & IF10 & NA & + & + \\
\hline 31 & IF11 & NA & \pm & \pm \\
\hline 32 & IF12 & NA & \pm & \pm \\
\hline 33 & IF13 & NA & + & + \\
\hline 34 & IF14 & NA & + & + \\
\hline 35 & IF 15 & NA & + & \pm \\
\hline 36 & IF16 & NA & \pm & \pm \\
\hline 37 & IF17 & NA & \pm & \pm \\
\hline 38 & IF18 & NA & \pm & \pm \\
\hline
\end{tabular}

Note: IB: Bacterial, IF: Isolate Fungi, +: positive antibacterial activity, -: negative antibacterial activity, \pm : has mist zoon.

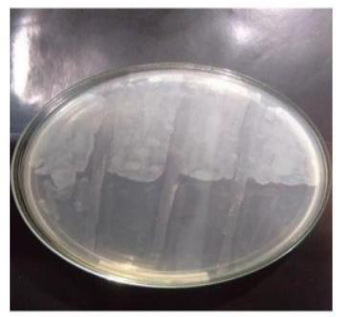

A

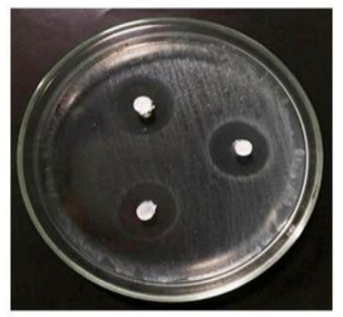

B
Figure 3. Antibacterial activity test of (1) bacterial isolates and (2) fungal isolates; (A) bacterial isolates, (B) pathogenic bacteria, (C) fungal isolates.
Table 2. Characterization Result of Bacterial Isolates

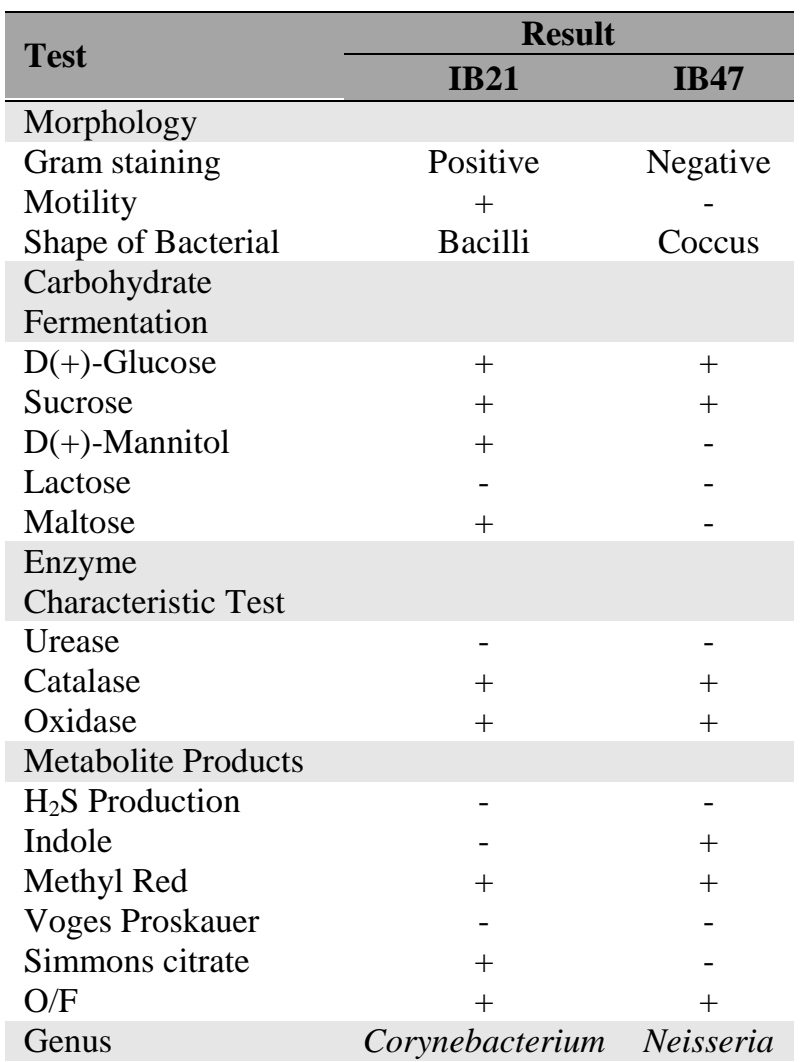

Note: +: positive test/growth; -: negative test/growth

Table 3. Characterization Result of Fungi

\begin{tabular}{ccc}
\hline Isolates & Colony Colour & Genera \\
\hline IF01 & Green & Trichocladium $\mathrm{sp}$. \\
IF02 & Brown & Aspergillus $\mathrm{sp}$. \\
IF03 & Light Brown & Chaetomium $\mathrm{sp}$. \\
IF04 & White & Coprinus $\mathrm{sp}$. \\
IF05 & Dark Brown & Cladorrhinum $\mathrm{sp}$. \\
IF06 & White Silver & Aspergillus $\mathrm{sp}$. \\
IF07 & Yellowish-brown & Hymeochaete $\mathrm{sp}$. \\
IF08 & Silver & Rhizopus $\mathrm{sp}$. \\
IF09 & Yellowish-brown & Hymeochaete $\mathrm{sp}$. \\
IF10 & White & Tremella $\mathrm{sp}$. \\
IF11 & White & Zygorhynchus $\mathrm{sp}$. \\
IF12 & White & Aspergillus $\mathrm{sp}$. \\
IF13 & Yellowish White & Mucor $\mathrm{sp}$. \\
IF14 & Purple & Bjerkandera $\mathrm{sp}$. \\
IF15 & Dark yellow & Chaetomium $\mathrm{sp}$. \\
IF16 & Silver & Aspergillus $\mathrm{sp}$. \\
IF17 & Gray & Chaetomium $\mathrm{sp}$. \\
IF18 & Dark green & Aspergillus $\mathrm{sp}$. \\
\hline
\end{tabular}

\subsection{Phytochemical Activity Test}

IB21 isolate has alkaloids and saponin compound (Table 4). The IB47 isolate has alkaloids, saponins and phenolics. Secondary metabolites in bacteria are formed during the stationary phase and along with the change in energy sources from macromolecules to bioactivity [36][37]. 
Table 4. Phytochemical Activity Test Result

\begin{tabular}{lll}
\hline \multirow{2}{*}{ Phytochemical Test } & \multicolumn{2}{l}{ Isolat } \\
\cline { 2 - 3 } & IB21 & IB47 \\
\hline Flavonoid & - & - \\
Alkaloid & & \\
Meyer & - & + \\
Dragendorff & + & + \\
Terpenoid & - & - \\
Steroid & - & - \\
Saponin & + & + \\
Phenolic & - & + \\
\hline Note: +: positive, -: negative &
\end{tabular}

\section{CONCLUSIONS}

The conclusions of this research were: 38 bacterial isolates and 18 fungal isolates were isolated from $C$. racemosa. Bacterial and fungal isolates had antibacterial activity against $S$. aureus and $E$. coli. Only two bacterial isolates namely IB21 and IB47 showed highest antibacterial activity. These two selected bacteria were characterized using biochemical test and they were identified as member of genus Corynebacterium and Neisseria, respectively. IB21 has positive in dragendorff (alkaloids) and saponins, IB47 has alkaloids, saponins and phenolics. Fungal isolates Trichocladium, Aspergillus, Chaetomium, Coprinus, Cladorrhinum, Hymeochaete, Rhizopus, Tremella, Zygorhynchus, Mucor, and Bjerkandera.

\section{REFERENCES}

[1] W. Merdekawati, A.B. Susanto, "Kandungan dan Komposisi Pigmen Rumput Laut Serta Potensinya Untuk Kesehatan”, Squalen, 4(2): 41-47, 2009

[2] E. Ferawati, D.S. Widyartini, I. Insan, "Studi Komunitas Rumput Laut Pada Berbagai Substrat Di Perairan Pantai Permisan Kabupaten Cilacap", Scripta Biologica, 1(1): 57-62, 2014.

[3] N.P.S. Maharani, N. L. Watiniasih, A.P.W.K. Dewi, "Struktur Komunitas Makroalga di Pantai Geger dan Pantai Mengening Kabupaten Badung", Simbiosis, XI(1): 51-61, 2021.

[4] M.S.J. Sofiana, I. Safitri, I., S. Helena, Warsidah, "Phytochemical Screening, Total Phenolic Content And Antioxidant Activity of Tropical Brown Macroalgae Padina pavonica Hauck From Kabung Island, West Kalimantan", Saintek Perikanan: Indonesian Journal of Fisheries Science and Technology, 17(1), 2021

[5] M.S.J. Sofiana, A.B. Aritonang, I. Safitri, S. Helena, S.I. Nurdiansyah, Risko, D. Fadly, "Proximate, Phytochemicals, Total Phenolic Content and Antioxidant Activity of Ethanolic Extract of
Eucheuma spinosum Seaweed", Sys. Rev. Pharm., 11(8): 228-232, 2020

[6] W. F. Yap, V. Tay, S. H. Tan, Y. Y. Yow, and J. Chew, "Decoding Antioxidant and Antibacterial Potentials of Malaysian Green Seaweeds: Caulerpa racemosa and Caulerpa lentillifera," Antibiotics (Basel, Switzerland) vol. 8,3 152. 17 Sep. 2019

[7] P. Proksch, R.A. Edrata, R. Ebel, "Drugs from the sea-current status and microbiological implication”, Appl. Microbiol. Biotechnol., 59: 125134, 2003.

[8] S. Rahmayanti, A. Massinai, S. Mashoreng, "Kepadatan Bakteri Simbion Rumput Laut (Eucheuma spinosum) yang Berasal dari Perairan Puntondo, Kabupaten Takalar, Sulawesi Selatan”, Proceeding Simposium Nasional Kelautan dan Perikanan. 2019 Oct 21(6)

[9] R.P. Nugroho, A. Budiharjo, E. Kusdiyantini, "Bioprospeksi Bakteri Yang Berasosiasi Dengan Alga Hijau Halimeda macroloba, Caulerpa racemosa, dan Ulva sp Sebagai Penghasil Senyawa Antibakteri", Jurnal Akademika Biologi, 2(4), 8-15, 2013.

[10] K. Utami, N. Idiawati, M.S.J. Sofiana, "Aktivitas Antibakteri Bakteri Berasosiasi Caulerpa rasemosa dan Caulerpa taxifolia dari Perairan Singkawang”. Jurnal Laut Khatulistiwa, 1(2), 55-60, 2018.

[11] Sartini, Suryadi, E.N. Zainuddin, "Isolation and Screening Fungal Symbiont in Green Alga Ulva reticulata as Candidate of Antibiotic Producer", Asian Jr. of Microbiol. Biotech. Env. Sc., 16(3): 475-478), 2014.

[12] D.A. Sumilat, R.A.J. Lintang. "Potensi antibakteri jamur Aspergillus nomius yang disolasi dari alga hijau Bornetella sp.”, Jurnal Ilmiah Platax, 9(1), 2021

[13] A. Ismail, L. Ktari, M. Ahmed, H. Bolhuis, A. Boudabbous, J. L. Stal, M. S. Cretoiu, and M. E. 1. Bour, "Microbial Activities of Bacteria Associated with the Brown Alga Padina pavonica," Front. Microbiol, 7:1072, 2016.

[14] A. C. Rahaweman, J. Pamungkas, H. Madduppa, C. Thoms, and K. Tarman, 2016, "Screening of Endophytic Fungi from Chlorophyta and Phaeophyta for Antibacterial Activity," J. IOP Conf. Series: Earth and Environmental Science, 1(31) : 17, 2016.

[15] W. Xie, P. Xu, W. Wang, and Q. Liu, "Preparation and antibacterial activity of a water-soluble chitosan derivative," Carbohydr. Res, 50:35-40, 2002. 
[16] A. Ismail, 2010, "Isolasi dan Identifikasi Mikroba Endofit Penghasil Antibiotika pada Alga Merah Eucheuma cottoni Asal Rappoa Kabupaten Bantaeng”, Universitas Islam Negeri Alauddin, Fakultas Ilmu Kesehatan, Jurusan Farmasi, Makassar, (Skripsi).

[17] Nurzakiyah, 2016, "Isolasi dan Identifikasi Molekuler Bakteri Endofit Caulerpa racemosa serta Aktivitas Antibakterinya Terhadap Staphylococcous aureus dan Methicillin Resistant Staphylococcous aureus (MRSA)," Universitas Islam Negeri Alauddin, Fakultas Sains dan Teknologi, Jurusan Biologi, Makassar, (Skripsi).

[18] R. Dewi, R. Nursanty, and C. Yulvizar, "The Effect of Storage Time on Total of Fungi in Kanji Pedah", J. Natural, 11(2) : 74-78, 2011

[19] D. Rizky, Warsidah, dan S. Helena, "Isolasi dan Identifikasi Fungi Berasosiasi Lamun Thalassia hemprichii dari Perairan Pulau Kabung", J. Laut Khat, 2(3) : 102-106, 2019.

[20] Yunaedi; Y. F. Victoria, L. Meylina, dan R. Rusli, "Isolasi dan Karakterisasi Jamur Endofit Akar Merung (Captosapelta tomentosa)", Prosiding Seminar Nasional Kefarmasian Ke-4, Samarinda: 20-21 Oktober 2016, Laboratorium Penelitian dan Pengembangan FARMAKA TROPIS Fakultas Farmasi Universitas Mulawarman Samarinda, Kalimantan Timur.

[21] C. G. Wang, J. Vlasa 'k, and Y. C. Dai, "Phylogeny and Diversity of Bjerkandera (Polyporales, Basidiomycota), Including Four New Species from South America and Asia", J. Myco Keys, 79: 149172. 2021.

[22] T. Watanabe, "Pictorial Atlas of Soil and Seed Fungi: Morphologies of Cultured Fungi and Key to Species", CRC Press LLC, U.S.A. 2010.

[23] Y. Zhao, X. Z. Liu, and F. Y. Bai, "Four New Species of Tremella (Tremellales, Basidiomycota) Based on Morphology and DNA Sequence Data", J. Myco Keys, 47: 75-95, 2019.

[24] T. Nie, Y. Tian, S. L. Liu, J. Yang, and S. H. He, "Species of Hymenochaete (Hymenochaetales, Basidiomycota) on Bamboos from East Asia, with Descriptions of Two New Species", J. Myco Keys, 20: 51-65, 2017.

[25] M. T. Mardigan, J. M. Martiko, J. Parker, 1997, "Antibiotics Isolation and Characteriation", In:MT Mardigan (ed) Brock Biology of Microorganism, 8th ed, Prentice-Hall International Inc, New York, 1997.
[26] J. Flewelling, K. T. Ellsworth, J. Sanford, E. Forward, J. A. Johnson, and C. A. Gray, "Macroalga Endophytes from the Atlantic Coast of Canada: a potential source of antibiotic natural products", J. Microorganisms, 1: 175-187, 2013.

[27] Andriani, “Aktivitas Antibakterial Fungi Endofit Caulerpa racemosa Terhadap Bakteri Escherichia coli dan Staphylococcus aureus", Prosiding Seminar Nasional Mikrobiologi Kesehatan dan Lingkungan, Makassar: 29 Januari 2015, Jurusan Biologi, Fakultas Sains dan Teknologi, UIN Alauddin, Makassar, 2015.

[28] F. Ahamed, and M. Murugan, "Isolation and Characterization of Marine Endophytic Fungi from Seaweeds and Bioactivity of Their Crude Extracts", J. of Pure and Applied Microbiology, 13(3) : 14511460, 2019.

[29] Suryanarayanan, T.S.; Venkatachalam, A.; Thirunavukkarasu N.; Ravishankar, J.P.; Doble, M. and Geetha, V., 2010, Internal Mycobiota of Marine Macroalgae from the Tamilnadu Coast: distribution, diversity and biotechnological potential, J. Botanica Marina, 53: 457-468.

[30] A. Venkatachalam, R. M. B. Govinda, N. Thirunavukkarasu, and T. S. Suryanarayanan, "Endophytic Fungi of Marine Algae and Seagrasses: a novel source of chitin modifying enzymes", J. Mycosphere, 6(3) : 345-355, 2015.

[31] N. Lekshmi, M. D. Umar, M. Dhaneesha, J. Rojin, R. Ravinesh, and T. P. Sajeevan, "Endophytic Fungi Isolated from the Marine Sponges as a Source of Potential Bioactive Compounds", J. of Aquatic Biology \& Fisheries, ISSN 2321-340X : 58-66, 2020.

[32] D. Handayani, N. Ananda, M. A. Artasasta, R. Ruslan, O. Fadriyanti, and T. E. Tallei, "Antimicrobial Activity Screening of Endophytic Fungi Extracts Isolated from Brown Algae Padina sp.”, J. of Applied Pharmaceutical Science, 9(03) : 009-013, 2019.

[33] A. Massinai, A. Tahir, J. Jompa, dan A. Rantetondok, "Bakteri Berasosiasi di Karang Batu (Skleractinia) yang Terinfeksi Penyakit Tumor (Growth Anomalies) yang Berasal dari Pulau Salemo Kabupaten Pangkep, Spermonde", 3(1): 712, 2017.

[34] B. E. Pratiwi, "Isolasi Dan Skrinning Fitokimia Bakteri Endofit Dari Daun Rambutan (Nephelium lappaceum L.) Yang Berpotensi Sebagai Antibakteri", Porgram Studi Farmasi, Fakultas Kedokteran Dan Ilmu Kesehatan, Jakarta, (Skripsi), 2015. 
[35] B. Ruiz, A. Chavez, A. Forero, Y. Garcia-Huante, A. Romero, and M. Sanchez, "Production of microbial secondary metabolites: Regulation by the carbon source". Crit. Rev. Microbiol. 36", 146-167, 2010 .

[37] Masriani, D. Fadly, and B. Bohari, " $\alpha$-Glucosidase Inhibitory Activity of Ethanol Extract Obtained from Dillenia suffruticosa and Pycnarrhena cauliflora", J. Glob. Pharma Technol, 12, 881-887, 2020 .
[36] D. Iqlima, P. Ardiningsih, dan M. A. Wibowo, "Aktivitas antibakteri isolat bakteri endofit B2D dari batang tanaman yakon (Smallanthus sonchifolius (Poepp. \& Endl.) H. Rob.) terhadap bakteri Staphylococcus aureus dan Salmonella thypimurium", Jurnal Kimia Khatulistiwa, 7(1), 2017.

[38] M. Ventura, C. Canchaya, A. Tauch, G. Chandra, G. F. Fitzgerald, K. F. Chater, and D. S. Van, "Genomics of Actinobacteria: tracing the evolutionary history of an ancient phylum", Microbiol. Mol. Biol. Rev, 71, 495-548, 2007. 